\title{
經 驗
}

\section{小倉記念病院半年間の經驗}

\section{小倉記念病院耳鼻咽院科}

末光喜代三 武田二郎

私（未光）が昭和25年 5 月下旬小倉記念病院に赴任 してから同11月12日後任野崎君に引渡寸迄の約半年間、 武田二郎君の協力の下に行つて來た臨休經驗を、主と して手術を中心として報告する。

私達が牛年間に經驗した手術例數は第 1 表及び第 2 表に示す通りである。

第 1 表一般手術

\begin{tabular}{|c|c|c|c|c|c|c|c|c|c|c|}
\hline & 耳 & 畧 1 & II & I & IIII & $V$ & 其他 & 咽 I & II & 計 \\
\hline & & 6 & & & 10 & 7 & & & 1 & 30 \\
\hline & & & & & & 1 & & & 0 & 25 \\
\hline & & 9 & 7 & 5 & 3 & 9 & 1 & 25 & 1 & 60 \\
\hline & 3 & 8 & 6 & 0 & 5 & ? & & 2 & 1 & 32 \\
\hline & & 4 & 2 & 3 & 1 & 2 & & 1 & 2 & 16 \\
\hline 月 & & 2 & 1 & 1 & 3 & 1 & & 4 & 0 & 12 \\
\hline 勤 & & 34 & 22 & 14 & 29 & 22 & 3 & 36 & & 175 \\
\hline
\end{tabular}

(11月12日現在)

耳の手術 6 例の內譯は耳後熯孔閉鉒術 1 例、乳樣䗋 倮㸮開術 2 例、耳根治手術 3 例である。

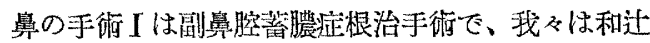

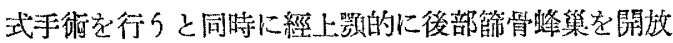
し、後日舅內的に前部箱骨蜂巢を開放したものである。

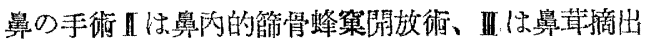
である。私達は外來息者の鼻茸を摘出する際には進ん で同時に節骨蜂黛安開放するる事が多い(14例中約本數)。

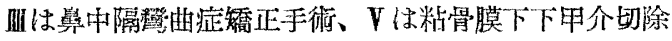
㱒である。我及は甲介切除術はやつていない。其他と

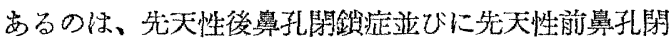
鎖泟瞦者に整㔙手術を行つたすのである。

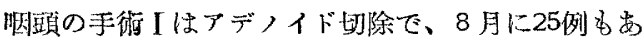

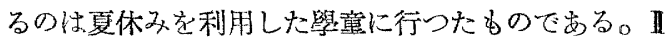
は口篮徧桃の摘出である。我及は㫘㘋性アンギーナが あるとか或はこのるのが病樂になる時の夕文手術適應
と考えているので症例數はあまり多くはない。殊に私 は患者を大院せしめ、手峏には絞斷器を使用しないで 最後迄剩離で完全に摘出する方法学探用している。

第 2 表には特殊の手術例定記載する。

第2表 特 殊 手 術

\begin{tabular}{|c|c|c|c|}
\hline 隆 鼻 術 & 1 & 側咽頭切開 & 1 \\
\hline 上颚 摘 出 & 1 & 下咽頭腫湯 & 1 \\
\hline 口蓋破裂 & 1 & 喉頭全摘 & 1 \\
\hline 顎下切開 & 1 & & \\
\hline
\end{tabular}

私達の行つている隆鼻術は皮下に合成樹脂のプロテ

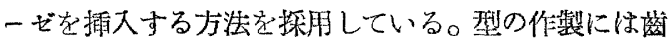
科の協力花得た。

颚下切開とあるのは舌根部膿瘃に對して行つたるの である。この症例は微後切開創があまりに早く閉鎖し た篇再發し、再度の手少を必要とした。

側咽頭切開は、咽頭側壁から侧頚部に涉る廣大なる

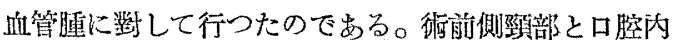
と兩側から術を進めるならば完全に摘出し得ると考元 たのであるが、筫際やつてみると血管腫を周圍組織か

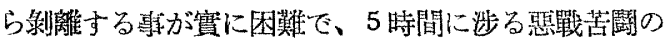
末、逐に摘出し得なかつた失敗例である。しかし其後

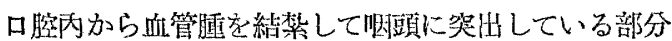
だけは縮少させ、息者の主訴である難聽・耳鳴は餘程 輕快せしぬ得た。寶はこの樣な大きい血管腫怔もとも と手術の邀倠ではない。

口䇺破裂とあるのほ、1 战生の幼兒で寢んた際竹の

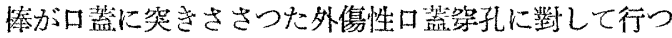

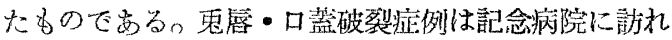
る旁が少い。これは小倉蓠科醫大に行く篇だとの事で ある。蕉ひでどんどん整形手術をすならば自然に䍐者 手勧まるであろら。

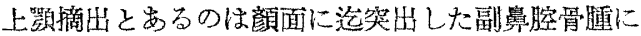
對して行つたるのである。患者は24葴の女性で20年前 郎ち 4 瓷の時加ら右側の斯根部に無痛性の腫庼を生じ、 それが次第に㵂大したるのである。20年間何等の治療

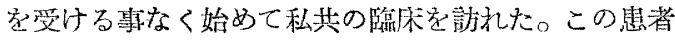

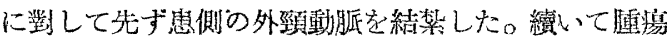


摘出に移つたのであるが、あまりに巨大である签やむ

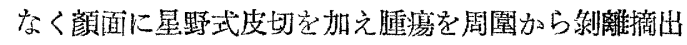
した。しかし腫瘍があまりにも巨大なる篇と節骨天篮

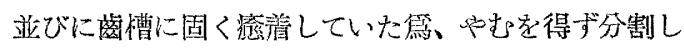

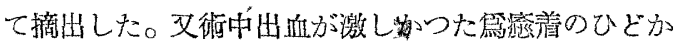
つた穊骨天盖と齒槽とには腫場の一部が殘してある。

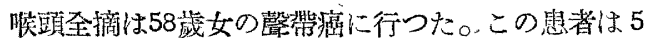
年前から馨が榎れ始めたと訴元て參りましたが、久末 寸と警帶の前 $1 / 3$ の所にポリープがある他は、政帶は 兩側共よく動き外頸部にリンパ腺徆脹定認めません。 それでこれは單純なるポリープで岁ると颜斷してポリ ープを摘出しましたが慗は一向によくなりませ九。念 の箩む5一度組織をとつて誠べてみると腺樣癌であつ た。そこでクロー氏法により喉磌全摘を行つた。県後 啹頭を開いてみると左側の馨带に限局した非常に小さ

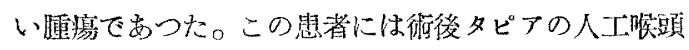
毒使用した。

以上が头和間に行つた賽樍であるが、この外に手術 を約柬しながら施行し得なかつた患算が多數める。私 がこの病院に赴任して最子悲しく思つた事は照者が約 束の日に來ない事であつた。結局私に信用がなかつた 隹であろ5。或は耳鼻科領域の慢性疾舁では手術をし てもなおらないとこの地方の息者は思い达んでいるの

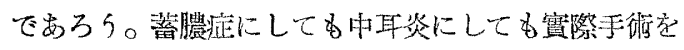
受けてもよくならず、それ所か耳の後に大きな穴を持

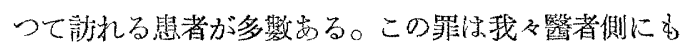
める。第 1 には過去の手術法が不完全であつたこと、 第2には經驗のない自信のない術者が手術を行5㑿の むのであろ5。手術法に就いて言らならば10年前に比 し今日では警異的の進步がみられる。しかし如何に手

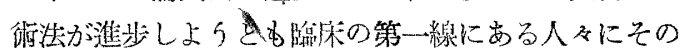
找能がなければ折角の進步む普及しない。結局手術を

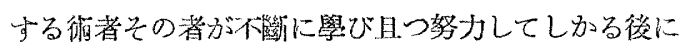

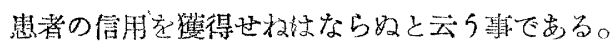

次に第 3 表に外來㭧者數と入院㭧者數安表示寸可。

\begin{tabular}{rrrrrr}
\multicolumn{7}{c}{ 第3 表患 者 } & 延 & 數 & \\
\hline 6 月 & 2257 & $(2158)$ & 102 & $(100)$ \\
7 月 & 1884 & $(2580)$ & 136 & $(89)$ \\
8 月 & 2227 & $(3206)$ & 128 & $(78)$ \\
9 月 & 1560 & $(2835)$ & 222 & $(72)$ \\
10 月 & 1605 & $(2927)$ & 151 & $(79)$ \\
11 月 & 725 & $(1087)$ & 34 & $(68)$ \\
\hline
\end{tabular}

（11月12日現住）（）內は昨年度
この樣な莫大な腎者數及び手術例、その量並び質

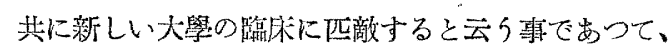
この樣な成瀨は一地方病院では到底望夕得ないことで ある。

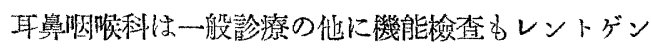

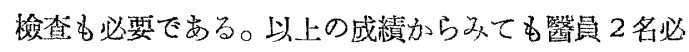
要である。所が10月以後は武田君の轉任により、私一 人で全てをやらねばならなくなつた。その篇外來・入 院共息者數は減少した。しかし私は一人で可能なる限

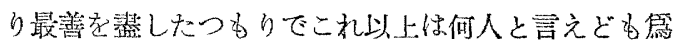
し得ない所であるとあさらめている。

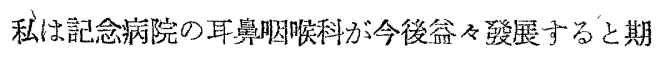
待しておる。しかしその罢には設備の上でも改善しな

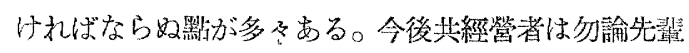
諸先生方の深き場理解と御同情とを期街する。

最後に私它當病院に招いて下さつた前院長副島譜溥 士に察く感謝の意虎裴する。

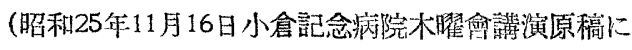
幾分䊖正を加之た。

\section{上顎癌の場合の牙關緊急}

$$
\text { 器厅幾一蚛（京大） }
$$

隐者は47留の女子。30年前より左側慢性副悬腔炎が あり、時々䶊茸摘出手術を受けていたが、昨年より急

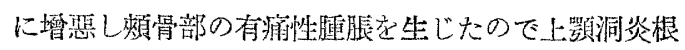
治手術定受けた。然し值然として腫脤疼湔は去らず且 2ヶ月前からは開口不能となつて來ている。

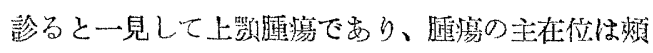
骨部である。之は後に扇本上皮癌であることがわかつ た。

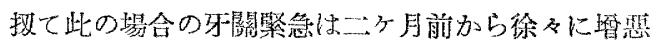

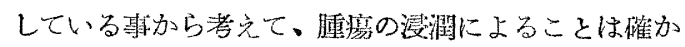
であるが、一體どの觔肉が括かされているのであろ か。煩骨部は沉發性に腫脹していて、咬筇它上方て觸

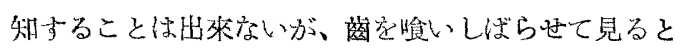

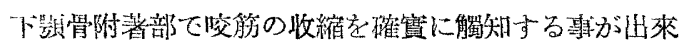

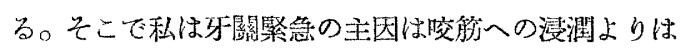
むしろ内外翼笑䈤への浸潤によるものであり、恐らく 癌は下䜾冠狀突起へる波及しているのではなかららか と考えた。ところが手術定行つて見ると癌は上䞄骨の 